\title{
Requiem for Regulation Q: What It Did and Why It Passed Away
}

\section{R. Alton Gilbert}

1) ARCH 1986 marked the end of the phase-out of interest rate ceilings on deposits, otherwise known as Regulation $Q$. The handwriting on the wall became evident for Regulation $O$ when the Monetary Control Act (MCA) of 1980 established the Depository Institum tions Deregulation Committee (DIDC), whose main duty was to phase out the resulation over a period of six years.

The purpose of this article is to review federal policy on deposit interest rate ceilings over the 53 years since they first were imposed. The article describes the objectives of Congress in establishing ceiling rates on deposits, examines their effects on the financial system and economic activity, and, finally, assesses the effect that phasing them out has had on the composi tion of deposit liabilities.

This analysis focuses on three distinct periods during which Regulation $\mathrm{Q}$ was administered under different objectives. In the first period, 1933 through 1965 , the ceilings constraned the interest rates paid by most commercial banks for only a few short intervals. During most of the second period, 1966 through 1979 , ceiling rates effectively constrained the rates paid by commercial banks and thrifts on at least some categories of their deposit liabilities. During the third period, 1980 through 1986, the DIDC gradually phased out Regulation Q, once again allowing market forces to determine deposit interest rates.

R. Alton Gibert is an assistant vice president at the Federal Reserve Bank of St. Louis. Laura A. Prives provided research assistance.

\section{W D

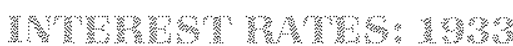

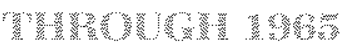

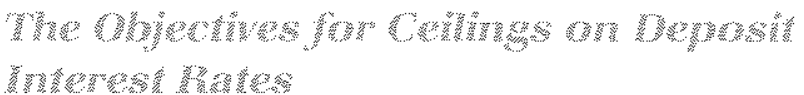

The Banking Acts of 1933 and 1935 prohibited the payment of interest on demand deposits and authorized the Federal Reserve to set interest rate ceilings on time and savings deposits paid by commercial banks. One important congressional objective was to encourage country banks to lend more in their local communities rather than hold balances with larger banks in financial centers. Critics of banking practices charged that the large banks in financial centers used these funds for speculative purposes, thus depriving businesses and individuals in smaller communities of credit that could have been used productively.

Supporters of the prohibition of interest on demand deposits also expressed concern that interbank bal-

\footnotetext{
The Banking Act of 1933 established controls over deposit interest rates for commercial banks that were members of the Federa: Reserve System. Nonmember commercial banks became subject to the same controls in the Banking Act of 1935. Mutual savings banks and savings and loan associations were exempt from the ceiling interest rates on deposits until the fall of 1966. Reasons for congressionally established interest rate ceilings in the $1930 \mathrm{~s}$ are discussed in Cox (1966), pp. 1-30, House Committee on Banking and Currency (1966a), pp. 651-53, Linke (1966), and Haywood and Linke (1968).
} 
Figure 1

\section{Effect of a Deposit Interest Rate Ceiling on Bank Profits}

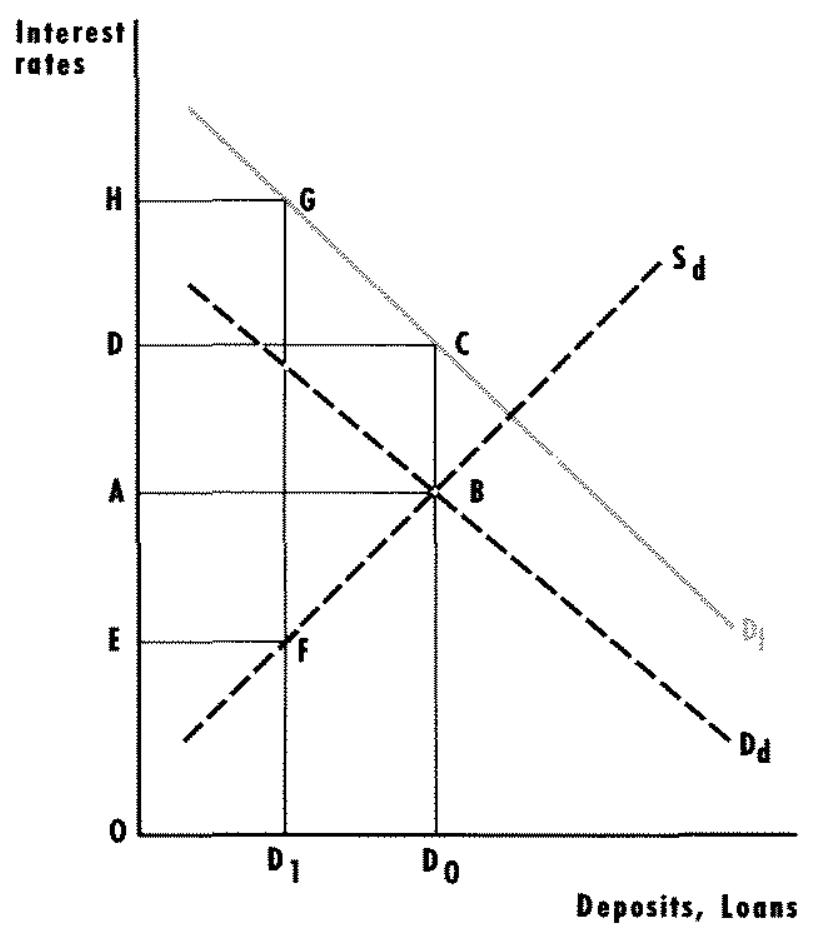

ances were adversely affecting the liquidity of the banking system. When smaller banks had an outflow of reserves, because of seasonal patterns in deposits and loan demand or occasional fnancia panics, they withdrew their deposits from their large correspondent banks in the financial centers. These withdrawals made it more difficult for the large comespondents to meet the cash demands of their nonbank customers. In its role as lender of last resort, the Federal Reserve had been established in 1914 to deal with these liquidity problems. In the 1930s, however, Congress still believed that interbank balances created liquidity problems for the banking system.

Another objective of ceiling interest rates on deposits was to increase bank profts by limiting the competition for deposits. Congress felt that competition for deposits not only reduced bank profits by rasing interest expenses, but also might cause banks to acquire riskier assets with higher expected returns in attempts to limit the erosion of their profits.

'Benston (1964) and Cox (1966) develop evidence from bank data for the 1920 s and 1930 s that is not consistent with the view that competition for deposits contributed to bank failures.
Bank protests about the cost of federal deposit insurance premiums provided a fral justification for interest rate ceilings. Some members of Congress believed that the savings in interest expense resulting from interest rate ceilings on deposits would exceed the deposit insurance premiums.

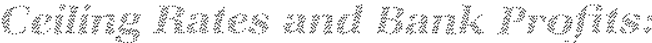

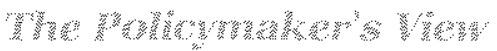

Some of the objectives mentioned above are based on the belief that banks' profits could be increased by imposing ceiling rates on deposits. The effects of these ceilings on bank profits are not as obvious as their effects on incentives to hold demand deposits.

Figure 1, which is used to illustrate the effects of ceiling rates on bank profits, depicts the supply and demand for loans and deposits in the banking system. To simplify the presentation, the dollar amount of loans is assumed to equal the amount of deposits at each level of deposits. The solid line is the demand curve for loans from the banking system. The dashed line labeled $\mathrm{D}_{\mathrm{a}}$ is the demand curve for deposits. The demand for deposits is based on the demand for loans. For each dollar amount of loans demanded, the interest rate that banks are willing to pay on deposits is somewhat less than the interest rate they can receive on loans; the difference determines bank profits. The banking system is assumed to be competitive. The profits are just large enough to yield a rate of return on the capital of the banking system comparable to returns on equity in other industries with similar risk." The other dashed line, labeled $\mathrm{S}_{\mathrm{d}}$, is the supply curve of deposits to banks; it indicates the inferest rates that banks must pay to attract various dollar amounts of deposits.

With no interest rate controls, banks will pay the interest rate $O A$ on deposits and chatge $O D$ on loans.

The capital of the banking system is assumed to equal the noninterest-bearing reserves of banks plus the value of their physical investment in banking offices. Banks are assumed to maintain a constant ratio of capital to deposits. When deposits change, banks change their reserves and the value of their offices by the same percentage as the percentage change in their deposits. If deposits decline, banks reduce their loans by the same dollar amount and reduce capital by making a special dividend payment to their shareholders. If deposits rise, the shareholders make additional investments in the bank to raise capital.

"The spread between the demand curve for loans and the demand curve for deposits is wider at higher levels of interest rates. This leature of the curves in figure 1 reflects the fact that the return on capital of the bank necessary to attract the investment of the bank's shareholders is higher when interest rates are higher. 


\section{Chart 1}

\section{Interbank Balance Ratios}

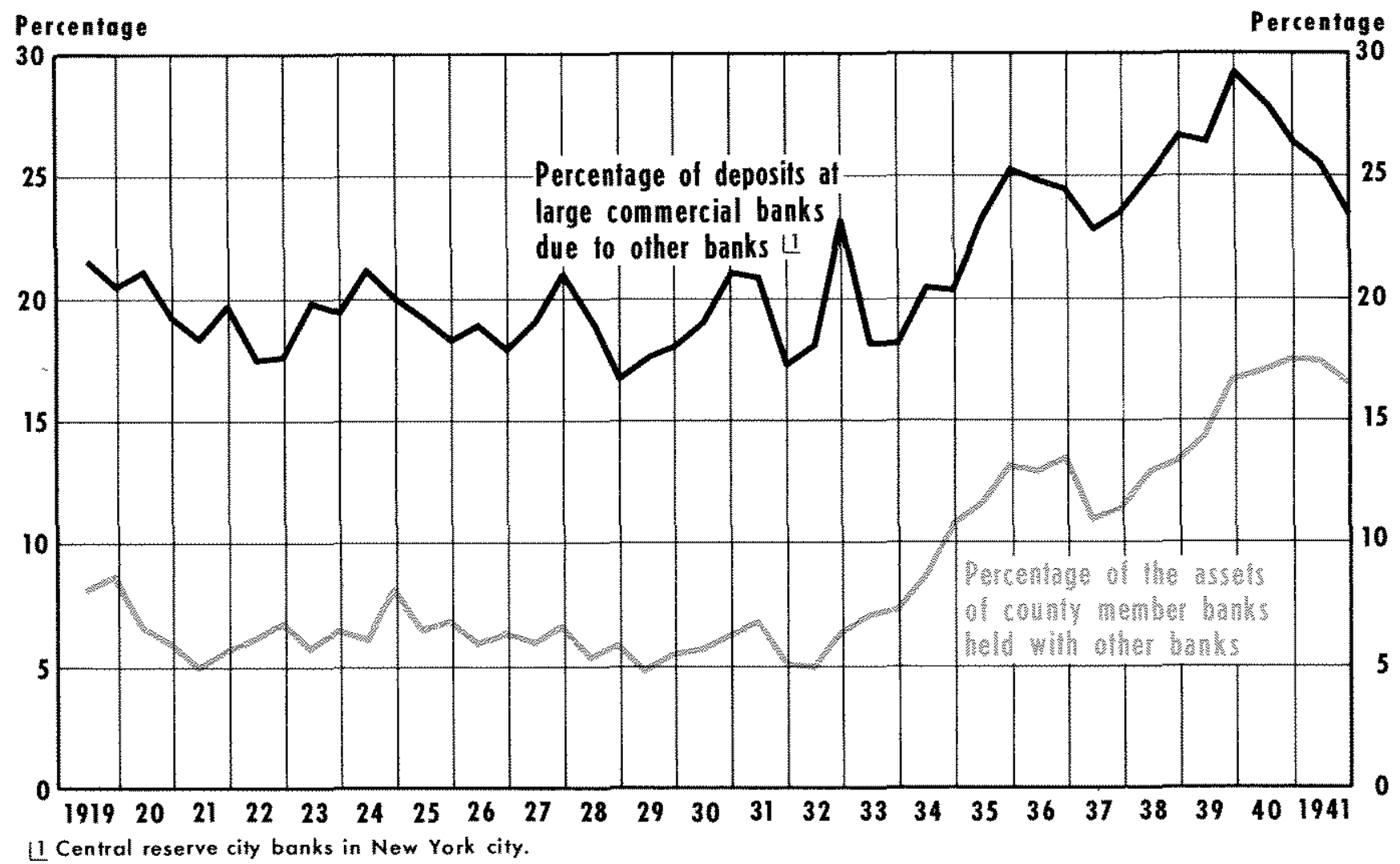

11 Central reserve city banks in New York city.

The level of deposits and loans will equal $D_{n}$. The profits of the banking system equal ABCD. Suppose the government considers these profits to be too small for a safe and sound banking system and sets a ceiling interest rate on the deposits of $O E$ that is below the rate $\mathrm{OA}$ that banks would pay with no ceiling rate in effect. With that ceiling rate, the quantity of deposits that banks can attract falls to $D_{3}$. With a lower level of deposits to lend, the interest rate on loans rises to $O H$. The profits of the banking system shift from ABCD to EFGH.

Imposing the ceiling interest rate on deposits does not necessarily increase the profits of the banking system. The difference between profits with the ceiling rate in effect and profits with no ceiling rate depends on the shapes of the demand curve for loans $\left(D_{t}\right)$ and the supply curve of deposits $\left(S_{t}\right)$. Congress assumed implicitly that the slopes of these two curves were sufficiently steep that the banking system's profits would be higher with a celling rate on deposits below the rate banks would pay with no ceiling in effect..

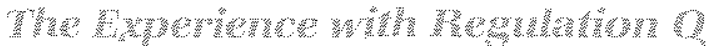 Cencher}

One major reason for interest ceilings on demand deposits was to reduce the incentives for relatively small banks to hold deposits with larger banks in the major financial centers. Small commercial banks, however, did not reduce the share of their assets held as deposits with other banks, but instead increased that share from about 5 percent in 1932 to about 17 percent by 1941 (chart 1). As another indicator of this

\footnotetext{
5A more thorough examination of the effects of deposit rate ceilings on bank profits would incorporate the effects of non-interest competition. Profits would be reduced il banks respond to ceilings that restrain the interest rates they pay on deposits through non-interest expenditures. The implications of non-interest comperition for deposits are considered in the section below that examines the effects of Regulation Q policy in the period 1966 through 1979.
} 


\section{Chort 2}

\section{Interest Rates and the Ceiling Rates on Time and Savings Deposits}

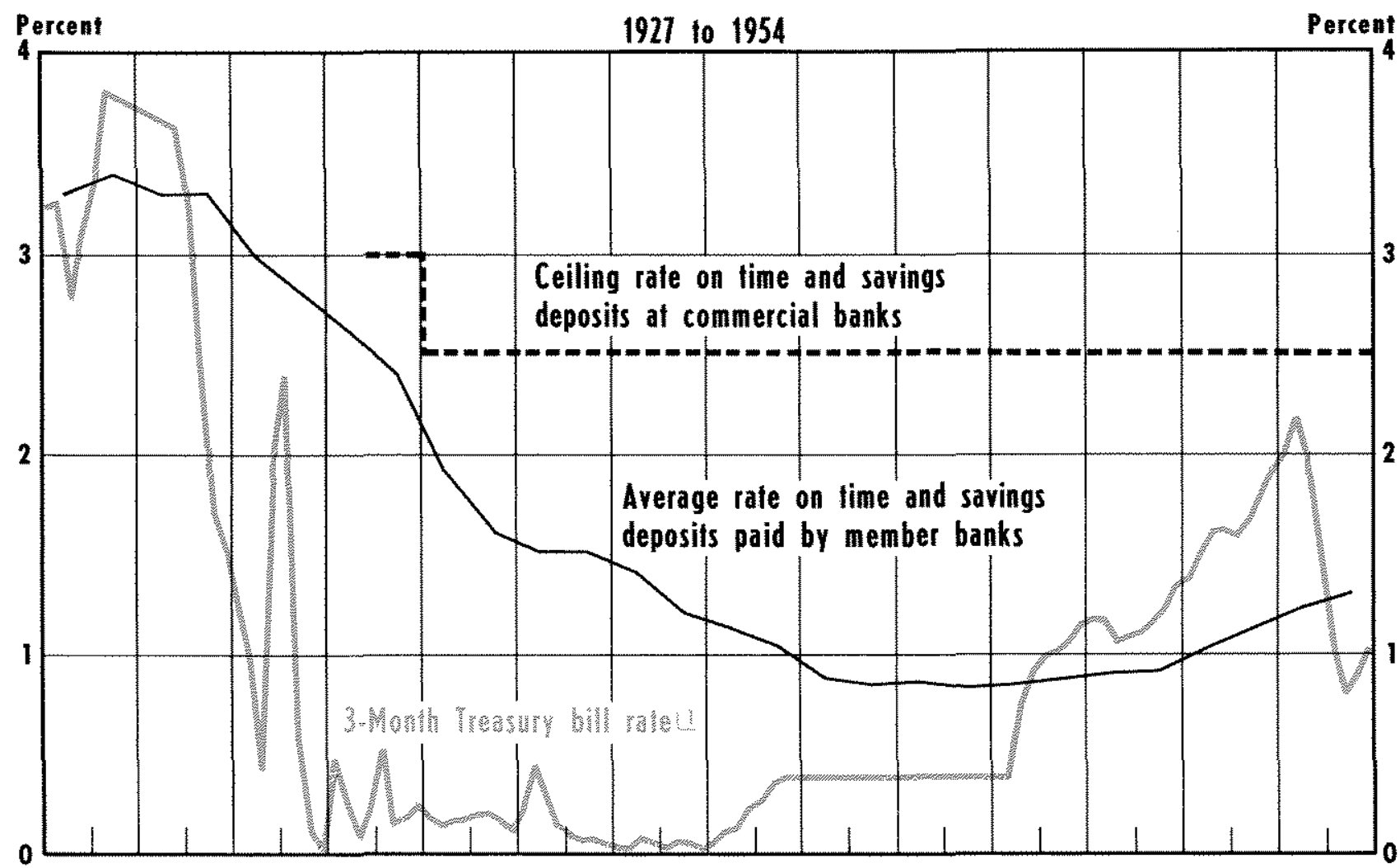

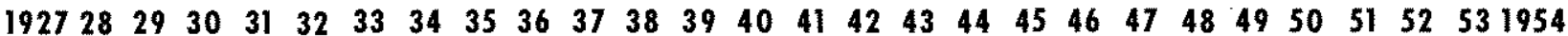

NOTE: All data are quarterly except the average rate paid on time and savings deposits which is an annual series.

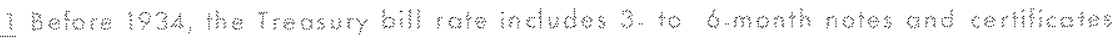

trend, the ratio of interbank deposits to total deposit liabilities rose at central reserve city banks from about 17 percent in 1932 to about 24 percent by 1941 . The increase in each ratio reflected the desire of banks to keep a larger proportion of their assets in liquid form after the banking crises of the early 1930s. What's more, the opportunity cost of holding interbank demand deposits was relatively low in 1933 , as it was throughout the rest of the 1930s. In the years 1933 through 1939 , the yield on newly issued Treasury bills averaged only 22 basis points.

On November 1, 1933, the Federal Reserve set the ceiling interest rate on all time and savings deposits at 3 percent (chart 2). The average interest rate that member banks paid on time deposits was 2.8 percent in 1932 and 2.6 percent in 1933 . The ceiling rate of 3 percent, therefore, was above the rate that banks had been paying on time deposits shortly before it was imposed. In 1934, the first full year for member banks under Regulation $\mathrm{Q}$, the average interest rate paid by member banks on time deposits was 2.4 percent. Thus, most member bank deposits did not yield the ceiling rate of 3 percent that year. The yield on shortterm Treasury securities was below 1 percent, while the yield on 4-to-6 month commencial paper was 1,25 percent in November 1933. Thus, this initial ceiling rate on time and savings deposits was above both the rates being paid by member banks and short-term market rates.

The ceiling rate on all time and savings deposits was lowered to 2.5 percent on February 1,1935 . The average interest rate paid by member banks on time deposits in 1935 was 1.9 percent, while most short-term market interest rates were under 1 percent.

These early observations indicate that the Federal 
Reserve interpreted its mandate for administering Regulation $\mathrm{O}$ to restrain the especially aggressive banks from offering such high interest rates on deposits that they would get into financial trouble. It does not appear that the Federal Reserve pursued the policy, analyzed above, of attempting to increase the profits of the banking system by setting deposit ceiling rates below the rates that most banks would have paid with no ceilings in effect.

From the mid-1930s to the mid-1960s, the ceiling rates on time and savings deposits generally were above market interest rates and above the average interest rates paid on time and savings deposits by member banks. In 1957 and 1962, when market interest rates rose near or above the ceiling rates on savings deposits, these ceilings were raised (see chart 3 on page 29 . Thus, for the finst 30 or so years of their existence, celling interest rates on time and savings deposits were above interest rates on Treasury securities in all but a few months, and the average interest rates paid by member banks on all time and savings deposits were below the lowest ceiling rate in effect, the rate on savings deposits.

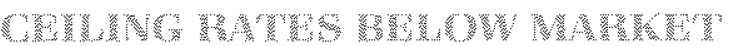 r.

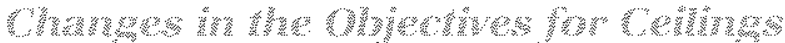

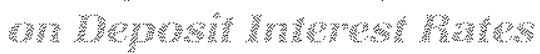

Regulation Q policy was changed in 1966, when interest rate ceilings were imposed on thrift institutions (mutual savings banks and savings and loan associations/. In contrast to the earlier period examined above, 1966 began a period of ceiling rates on at least some categories of time and savings deposits at commercial banks that were kept below Treasury bill rates.

The change in Regulation $Q$ policy in 1966 reflected the dissatisfaction of policymakers with the performance of the financial system. Interest rates had risen sharply in 1965 and 1966 . The three-month Treasury bill rate had risen fiom 3.84 percent in September 1965 to 5.37 percent in September 1966. Over that period, interest rates on residential mortgage loans had risen from 5.80 percent to 6.65 percent.

Policymakers became more and more concerned about the allocation of credit. In 1966 the volume of funds raised by business firms in the financial markets

6Ruebling (1970). rose sharply relative to the funds raised by households in the form of residential mortgages. The slowing in the rate of increase in residential mortgage credit was especially pronounced at thrift institutions.?

The changes in Regulation $\mathbf{Q}$ ceiling rates reflected policymakers' interpretation of these events. Supporters of legistation that changed Regulation $Q$ policy considered the competition for deposits between commercial banks and thrifts one of the primary causes of the general rise in interest rates. They argued that deposit interest rate ceilings must be extended to thrifts to limit this rise.

Supporters of the legislation also thought that the diversion of credit from residential mortgages to credit for business fims could be reversed by limiting the interest rates that commercial banks could pay on deposits. Since commercial banks were considered the thrifts' primary competitors in attracting deposits, thifts could make more mortgage credit available at lower interest rates if they were shielded from such competition.

In the fall of 1966, interest rate ceilings on deposits were set slightly higher at thrifts than at commercial banks. Higher ceiling rates at thrifts were intended to induce depositors at commercial banks to shift their deposit accounts to thrift institutions. Policymakers assumed that thrifts then would increase the amount of mortgage credit available to homebuyers and lower their mortgage interest rates. "This policy initially was described as a temporary one to deal with unusual circumstances. Over time, however, many in the thrift institution industry came to view the new Regulation Q policy as essential for them to attract deposits and make mortgage loans. ${ }^{\text {. }}$

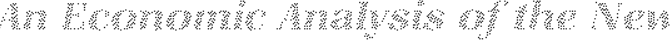

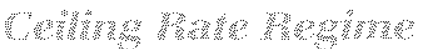

Figure 2 illustrates the supply and demand for deposits at commercial banks and thrift institutions. This analysis has two purposes: first, to model the effects of Regulation $Q$ policy anticipated by policymakers, and second, to illustrate why this policy did not yield the anticipated results.

'See testimony in House Committee on Banking and Currency (1966b) and Senate Committee on Banking and Currency (1966).

"Savings and loan associations and mutual savings banks, which specialize in residential mortgage lending, are identified as thrift institutions.

sFor a statement by a government policymaker that defends Regulation $Q$ as a means of promoting the flow of credit to residential mortgages, see Martin (1970). 
Figure 2

Effects of Ceiling Interest Rates on the Deposits of Commercial Banks and Thrift Inslitutions
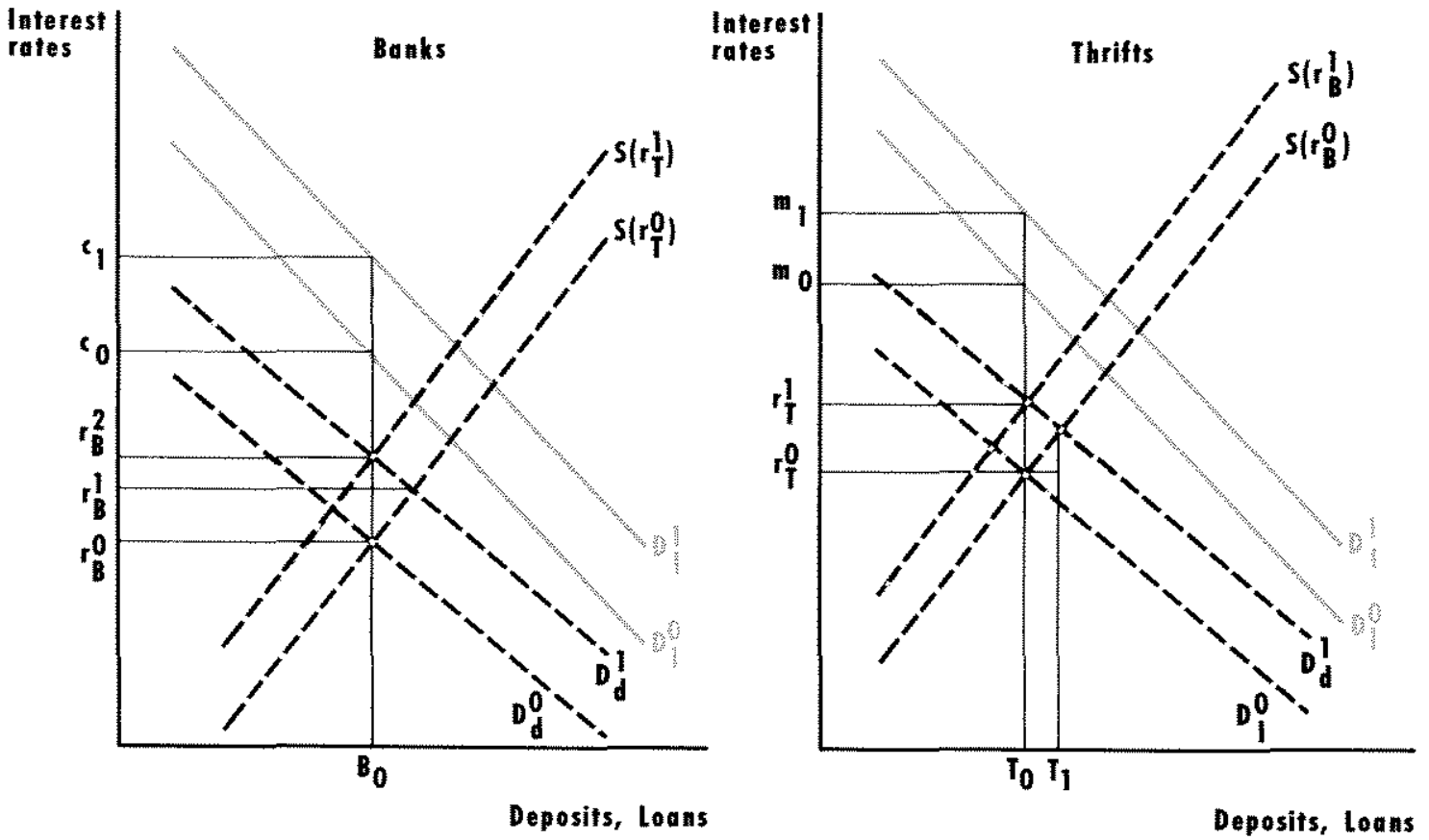

W.2.

Some of the assumptions underlying figure 1 are also employed in constructing figure 2 : For commercial banks and thrifts, deposits are assumed to equal loans. The spread between the demand curve for loans and that for deposits represents the competitive return on capital. To depositors, commercial banks and thrifts are close, but not perfect, substitutes. If, for instance, commercial banks increase the interest rate they offer on deposits relative to the rate offered by thrifts, some, but not all, depositors will shift their accounts from thrifts to commercial banks. This interaction is modeled in figure 2 by making the position of the supply curve for one kind of institution depend on the interest rate paid by the other kind. For instance, if commercial banks increase the interest rate they offer on deposits $\left(r_{B}\right)$, the supply curve of deposits to thrifts will shift to the left.

Thrift institutions are assumed to specialize in mortgage lending, while commercial banks speciatize in business and consumer lending. Given this specialization, the demand curve of loans from each type of institution is assumed to be independent of the interest rate that the other type of institution charges for loans.

Suppose, initially, that thrifts pay a slightly higher interest rate on deposits than commercial banks, i.e., that $r_{\%}^{0}$ exceeds $r_{8}^{0}$, and the rate $r_{8}^{0}$ equals the ceiling rate on deposits at commercial banks. ${ }^{\text {to }}$ In the initial equi librium, the demand for loans at each type of institution is labeled $D_{1}^{a}$ and the demand for deposits is labeled $D_{d}^{a}$; the initial level of deposits and loans is $B_{0}$ at commercial banks and $T_{\theta}$ at thrifts; and the initial rates charged on loans are $c_{v}$ (banks) and $m_{0}$ (thrifts)

Now, suppose that the demand for loans at both commercial banks and thrifts increases, represented by shifts in the demand curves from $D_{1}^{a}$ to $D_{t}^{1}$. The demand curves for deposits shift up to $D_{d}^{1}$, maintaining the same spreads between the demand cuves for loans and those for deposits at each level of interest rates.

Policymakers must either raise the ceiling rate on deposits at commercial banks in response to the rise in the demand for credit or keep the ceiling rate at $r_{\mathrm{B}}^{0}$. Given the nature of Regulation Q policy prior to 1966 , the ceiling rate on bank deposits would have been raised enough to avoid constraining the ability of commercial banks to compete for deposits. In 1966, in

to This supposition describes what actually occurred before late 1966; thrifts, did, in fact, pay higher interest rates on deposits than commercial banks betore the fall of 1966. See Clements (1966). 
contrast, policymakers decided to keep the ceiling rates at levels that would limit the rates that banks could pay on deposits and impose similar ones on thrifts. The objectives of the new policy can be illustrated by comparing the effects of the increase in credit demand with and without the binding ceiling rates on deposits.

First, consider the case in which the ceiling rate is raised enough to place no constraint on the rates paid by commercial banks and no ceiling rate is imposed on thrifts. The effect of the increase in the demand for credit on the rates paid on deposits can be analyzed as a series of interactions between the rates paid by commercial banks and those paid by thrifts. With thrifts initially paying the rate $r_{\mathrm{s}}^{0}$ on deposits, the rate paid by commercial banks rises to $r_{k}^{1}$. With commercial banks paying the rate $r_{k}^{\prime}$, the supply curve of deposits at thrifts shifts to the left to $\left.S\left(\Gamma_{1}^{1}\right)\right\}$. The rise in the demand for loans at thrifts and the rise in the interest rate paid on deposits by commercial banks create an excess demand for deposits at thrifts. In response, the rate they offer to pay on deposits rises to $\mathrm{r}^{\mathrm{r}}$. The next step in the adjustment of deposit rates to the rise in the demand for credit involves a shift in the supply curve of deposits at commercial banks to the left $\left(S\left(r_{1}^{\sharp}\right)\right)$, causing the rate paid by commercial banks to rise to $r_{k}^{2}$.

Statements by the policymakers who advocated the change in Regulation Q policy in 1966 indicate that, after observing such interactions between the rates paid by commercial banks and thrifts, they concluded that interest rates were being driven higher by the competition. The increases in interest rates paid on deposits, in fact, represented the response by depository institutions to increases in the demand for credit.

The solution to the escalation of interest rates adopted by Congress was to impose ceilings on the deposit rates paid by thrifts and to set the ceiling rates for commercial banks and thrifts below the rates they would pay in the absence of ceilings. The ceiling rates were set slightly higher at thrifts to induce an inflow of deposits from commercial banks to thrifts, which would be used to make residential mortgage loans.

To illustrate how policymakers assumed this policy would work, suppose the ceiling tate for commercial banks is $r_{B}^{0}$ and for thrifts is $r_{*}^{*}$. Preventing an increase in deposit interest rates at banks and thrifts is supposed to keep the supply curves for deposits in their initial positions before the rise in the demand for credit ( $S\left(\mathrm{n}_{\mathrm{T}}\right)$ for commercial banks and $\mathrm{S}(\mathrm{f})$ for thrifts). Imposing the celling rates $\Gamma_{B}^{n}$ and $\mathrm{r}_{\mathrm{z}}^{\mathrm{u}}$ does prevent a rise in the interest expense of depository institutions after the rise in the demand for credit.

Figure 2 also illustrates, however, why the ceiling interest rates on deposits would not prevent increases in interest rates on loans charged by banks and thrifts. Suppose that after the rise in the demand for credit, the deposits and loans of banks are still $B_{0}$.yielding the ceiling rate $\Gamma_{t}^{(j)}$ and the deposits and loans of thrifts are $T_{0}$ (yielding $\Gamma_{r}^{t)}$ ). The interest rate charged by commercial banks on their commercial and consumer loans rises from $c_{0}$ to $c_{1}$ due to the rise in the demand for credit; the interest rate charged by thrifts on mortgage loans rises from $m_{q}$ to $m_{s}$.

It is not possible to draw a general conclusion about whether the mortgage thterest rate would have been higher with no controls on the interest rates paid on deposits or with the ceiling rates $r_{z}^{0}$ and $r_{3}^{0}$ in effect. The difference in the mortgage interest rate under these conditions depends on how responsive the supply of deposits at each type of institution is to the interest rate paid on deposits by the other type of institution." Additional influences on the supply of mortgage credit by thrift institutions analyzed in the following section, which policymakers seem to have ignored, would strengthen the argument that the Regulation $\mathrm{O}$ policy adopted in 1966 reduced the supply of mort gage credit by thrifts and raised mortgage interest rates.

The change in Regulation $Q$ policy in 1966 had the dual purpose of halting the escalation of interest rates paid on deposits and stimulating the expansion of mortgage credit. The fact that these objectives were inconsistent can be illustrated by referring again to figure 2 . If the primary objective was to stimulate thrifts to make more mortgage loans, policymakers should have set the ceiling rate on bank deposits low enough to constrain the rate paid by banks, but should not have put ceilings on the interest mates paid by thrifts. With the ceiling rate on bank deposits of $r_{3}^{0}$ the deposits and loans of thrifts would have been higher $\left(T_{1}\right)$ and the interest rate on mortgage loans lower if thrifts had not been constrained by the celling rates on theif deposits.

\footnotetext{
170 illustrate the basis for this conciusion, suppose that the supply curve of deposits at thrifts does not shith when there is a change in the interest rate paid on deposits by commercial banks; instead, that supply curve remains in the initial position of $S(r g)$. Under that assumption, the mortgage interest rate would be below $m_{1}$ with no ceiling interest rates on deposits after the rise in the demand for credit. In contrast, the farther the supply curve of deposits at thrifts shifts to the left for a given rise in the interest rate paid on deposits by commercial banks, the more likely it is that the mortgage rate would be higher under the condition of no interest rate controls on deposits.
} 
Chart 3

\section{Interest Rates and the Ceiling Rates on Time and Savings Deposits}

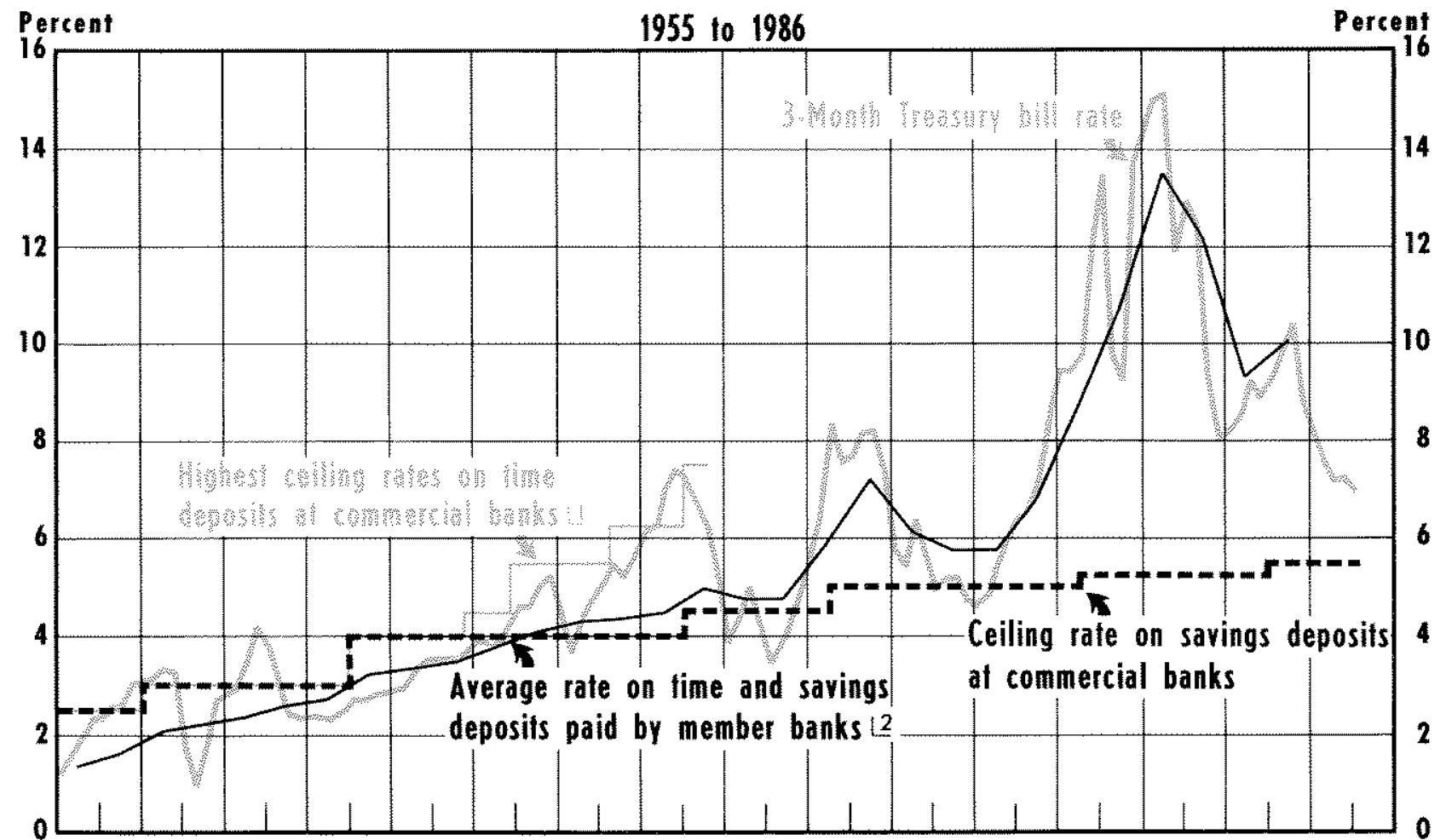

19555657585960616263646566676869707172737475767778798081828384851986

NOTE: All data are quorterly except the average rate paid on time and savings deposits which is an annual series.

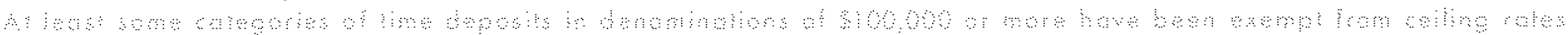

(a)

2 Atter 1971, the average interest rate is for all insured commercial banks.

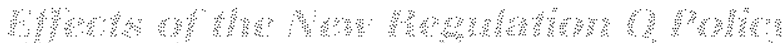

Ceiling rates on some categories of deposits were kept below the market rates on Treasury securities for most of the period from the fall of 1966 through March 1986 (chart 3). This policy did not isolate thrift institutions and the market for residential mortgages from the effects of fluctuations in market interest rates. When market interest rates rose relative to the ceiling rates, the growth of deposits at thrifts slowed "Fluctuations in the growth of deposits at thrifts may have contributed to the abrupt changes in the pace of residential construction activity; some studies, however, do not support the hypothesis that disintemediation at thrifts adversely affected residential con-

\footnotetext{
12Mckelvey (1978)
}

struction." Thus, the policy of imposing binding ceilings on deposit interest rates produced results that were inconsistent with the policy's stated goals.

There was another effect. Regulation Q policy altered the distribution of wealth in the economy. Deposit interest rate ceilings discriminated against the relatively less wealthy savers. "When market interest rates were above the ceiling rates, the wealthier inves-

\footnotetext{
t3jaffee and Hosen (1979) and Berkman (1979). The results of some studies, however, do not support the view that changes in the avallability of mortgage credit through thritt institutions influence residential construction. See Arcelus and Meltzer (1973), Meltzer (1974), and De Rosa (1978).

${ }^{44}$ Kane $(1970,1980)$, Clotfelter and Lieberman (1978), and Lawrence and Eliehausen (1981).
} 
tors shifted their deposits to money market securities. Moreover, deposits in denominations of $\$ 100,000$ or more were made exempt from Regulation $Q$ in June 1970. Investors without enough funds to buy money market instruments continued to hold their funds at commercial banks and thrifts in accounts subject to Regulation $Q$ ceiling rates. According to some studies, small savers lost several billion dollars in interest eamings as a result of Regulation $\mathrm{Q}$ ceilings. ${ }^{5}$

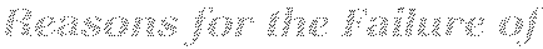

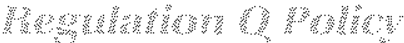

The reasons for the failure of Regulation $\mathrm{Q}$ policy to achieve the objectives established in 1966 can be analyzed by examining figure 2 . Setting the ceiling rate that banks could pay on deposits at $\mathrm{r}_{\mathrm{H}}^{\prime \prime}$ did not guarantee that thrifts could attract deposits of $T_{i}$ by paying the rate $\Gamma_{\text {r. }}^{0}$. Banks could attract additional deposits through various forms of non-interest expenditures. When interest rate ceilings on deposits were below the rates that banks would have offered with no ceilings in effect, banks competed for deposits by offering depositors a variety of gifts, "free" services, and new offices that were more conveniently located." These forms of non-interest competition shifted the supply curve of deposits at thrifts to the left of the line labeled $S\left(r_{b}^{0}\right)$. With the ceiling on thrift deposit rates at $r$, a shift in the supply curve of deposits to the left reduces the level of deposits and loans at thrifts and drives up the interest rate on mortgages. The various forms of noninterest competition for deposits by thrifts would also cause the supply curve of deposits for banks to shiff to the left.

Thus far, we have not indicated how interest rates other than those paid on the deposits of banks and thrifts influence the supply of deposits. When interest rates on securities such as Treasury bills rose above the ceiling rates on deposits at banks and thrifts, the growth of time and savings deposits declined at both types of institutions. "This effect can be illustrated by referring to figure 2. Suppose the market inferest rate on Treasury bills rises when the demand for credit rises at banks and thrifts. The mise in the Treasury bill rate shifts the supply curves of deposits to the left at both types of institutions. With ceiling rates $r_{b}^{*}$ and $r_{r}^{i}$ in effect, banks and thrifts can not respond directly by raising the interest mates they pay on deposits. As a

\footnotetext{
15Morgan (1979), Pyle (1974, 1978), and Taggart (1978).

towhite (1976), Taggart (1978), Spellman (1980), Kilcollin and Hanweck (1981), Peterson (1981), and Startz (1983).

17See Gibert and Lovati (1979).
}

result, deposits at both banks and thrifts fall and cause the interest rates on their loans to rise more than if they had been free to raise the interest rates they pay on deposits.

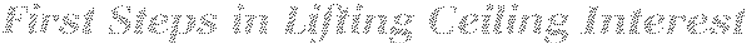

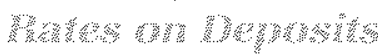

the problems caused by interest rate ceilings became more serious in the late 1970 s when market interest rates rose sharply (chart 3 ). In response, the regulators of depository institutions took limited steps to lift ceilings on some categories of time and savings deposits in denominations of $\$ 100,000 \mathrm{or}^{\circ}$ less.

The relaxation of ceiling interest rates on deposits in the late 1970 s is shown in table 1. Money market certificates (MMCs), authorized in June 1978, had interest rate cellings that floated with the yield on 6 month Treasury bills. T'erms on MMCs incorporated two features of Regulation $\mathrm{Q}$ policy in effect before June 1978: the ceiling rate for thrifts each week was 25 basis points higher than that at commercial banks, and, with a minimum denomination of $\$ 10,000$, the authorization of MMCs benefited only wealthy investors.

Another change in 1978 was the atthorization of automatic transfer service accounts at commercial banks, the first move at the national level toward the authorization of interest-bearing checkable deposits. Finally, small saver certificates (SSCs) were authorized in July 1979, with ceiling rates that floated with market interest rates; there was no minimum denomination on SSCs but a minimum initial maturity of 30 months.

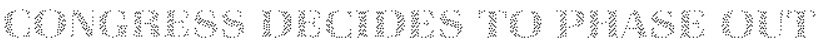 F.}

Sharp increases in interest rates in late 1979 and early 1980 , combined with Regulation $\mathrm{Q}$ ceiling rates (chart 3), induced large outflows of smalldenomination deposits from banks and thrifts. Money market mutual funds had become major competitors with depository institutions for small-denomination investment accounts, and investments in money market mutual funds grew rapidly during 1979 and early 1980 (chart 4). Realizing that Regulation Q was not yielding the desired results of restraining competition for deposits of increasing the supply of mortgage credit, Congress responded by passing the MCA in March 1980, which established a procedure for phasing out Regulation $\mathrm{O}$.

One of the most significant sections of the MCA calls 
Table 1

\section{Steps in the Phase-Out of Regulation Q}

Effective date

of change

June 1,1978

November 1, 1978

July 1,1979

June 2, 1980

June 5,1980

December 31, 1980 .

August 1, 1981

October 1,1981

November 1981

December 1,1981

May 1,1982

September 1,1982

December 14,1982

January 5,1983

April 1, 1983

October 1,1983

January 1,1984

January 1,1985

January 1,1986

March 31,1986

Tems:

S\&Ls _ savings and loan associations

MSBs - mutual savings banks

CBs_commercial banks:

MMCS - money market centificates CBS and 875 percent 5.25 percent of $3-1 / 2$ years CBs. permitted.
Nature of change

MMCs established, with minimum denomation of $\$ 10,000$ and maturities of 26 weeks The floating ceiling rates for each week were set at the discount yeld on six-month Treasury bills at $S \& L s$ and MSBs, 25 basis points less at

ATs accounts a allowing funds to be transferred automatically from savings to checking accounts as needed to avoid overdrafts. The ceiling rate on ATS accounts was set at 5.25 percent, the same as the ceiling rate on regular savings accounts at CBs.

SSCs established with no minimum denomination, maturity of 30 months or more and floating ceiling rates based on the yield on $21 / 2$-year Treasury securites, but 25 basis points higher at S\&Ls and MSBs. Maximums of 11.75 percent at CBs and 12 percent at S\&LS and MSBs

The floating celling rates on SSCs raised 50 basis points relative to the yield on $21 / 2$ year Treasury securities at S\&LS and MSBS and at CBS The maximum ceiling rates set in June 1979 were retained.

New floating ceiling rates on MMCs All depository nstitutions may pay the discount yeld on 6 -month Treasury bils plus 25 basis points when the bill rate is 8.75 percent or higher The celling rate will be no lower than 7.75 percent A rate differential of Up to 25 basis points favors S\&Ls and MSBS if the bill rate is between 7.75 percent

NW accounts permitted nationwide at all depository institutions. Ceiling rates on NOW and ATS accounts set at

Caps on SSCs of 1175 percent at CBS and 12 percent at $\$ \& L$ and MSBs eliminated. Ceiling rates foat with the yeld on $21 / 2$-year Treasury securties.

Adopted rules for the All Savers Certificates specified in the Economic Recovery Act of 1981

Floating ceiling rates on MMCs each week changed to the higher of the 6 -month Treasury bill rate fin the previous week or the average over the previous four weeks.

New category of IRAKeogh accounts created with minimum maturity of $1-1 / 2$ years, no regulated interest rate celling and no minimum denomination

New time deposit created with no interest rate ceiling, no minimum denomination and an initial minimum maturity

New short-tem deposit instrument created with $\$ 7,500$ minimum denomination and 91 -day maturity. The floating ceiling rate is equal to the discount yield on 91 -day Treasury bills for S\&LS and MSBS, 25 basis points less for

Maturity range of SSCs adjusted to $30-42$ months.

New deposit account created with a minimum denomination of $\$ 20,000$ and maturity of 7 to 31 days. The foating ceiling rate is equal to the discount yield on 91 wday Treasury bills for S\&Ls and MSBS, 25 basis points less for CBs. These ceiling rates are suspended if the 91 -day Treasury bill rate falls below 9 percent for four consecutive Treasury bill auctions.

MMDAs authorized with minimum balance of not less than $\$ 2,500$, no interest ceiling, no minimum maturity, up to six transfers per month (no more than three by draft), and unlimited withdrawals by mail, messenger or in person.

Super. NOW accounts authorized with same features as the MMDAs, except that unlimited transfers are

Interest rate ceiling eliminated and minimum denomination reduced to $\$ 2,500$ on 7 - to 31-day accounts.

Minimum denomination reduced to $\$ 2,500$ on 91 -day accounts and MMCs of less than $\$ 100,000$.

Minimum maturity on SSCs reduced to 18 months.

All interest rate celings eliminated except those on passbook savings and regular NOW accounts. Minimum denomination of $\$ 2,500$ established for time deposits with maturities of 31 days or less (below this minimum, passbook savings rates apply.

Gate differentia between commercial banks and thrifs on passbook savings accounts and 7 - to 31 -day time deposits of less than $\$ 2,500$ eliminated. All depository institutions may pay a maximum of 5.50 percent.

Minimum denominations on MMDAs, Super NOWs and 7 - to 31 day ceiling free time deposits reduced to $\$ 1,000$. Minimun denominations on MMDAs, Super NOWs and $7-1031$-day celing-free time deposits eliminated All interest rate celings eliminated, except for the requirement that no interest be paid on demand deposits.
SSCs - small saver certificales

ATS accounts - automatic transfer service accounts

Now accounts - negotiable order of withdrawal accounts

MMDAs - money market deposit accounts 
Chart 4

\section{Small Time and Savings Deposits at all Depository Institutions and Investments in MMMFs}

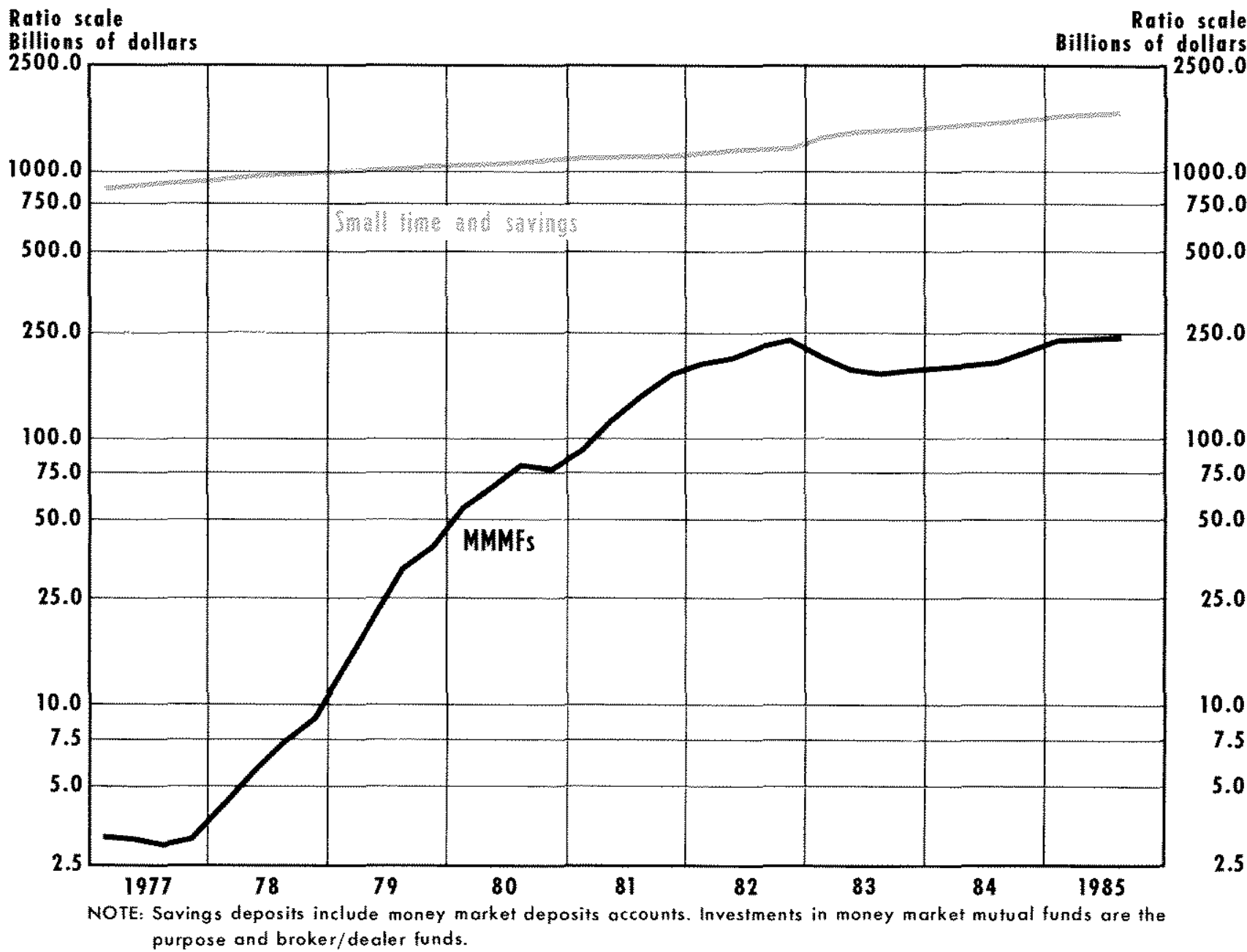

for the elimination of ceilings on deposit interest rates over a six-year period. The statement of findings and purpose in that section of the act reads as follows:

The Congress hereby finds that

(1) limitations on the interest rates which are payable on deposits and accounts discourage persons from saving money, create inequities for depositors, im pede the ability of depository institutions $10 \mathrm{com}-$ pete for funds, and have not achieved their purpose of providing an even flow of funds for home mortgage lending; and

(2) all depositors, and particularly those with modest savings, are entitled to receive a market rate of return on their savings as soon as it is economically feasible for depository institutions to pay such rate."s

The act did not establish a specific timetable for eliminating deposil interest rate ceilings, but delegated those decisions to a newly created committee: the DHDC. Voting members of the DIDC included the secretary of the Treasury and chairpersons of the Federal Reserve Board, Federal Deposit Insurance

${ }^{18}$ Depository Institutions Deregulation and Monetary Control Act (1980), tite 11, sec. 202 (a). 
Corporation, Federal Home Loan Bank Boand, and National Credit Union Administration. The Comptrollev of the Currency was a non-voting member of the DIDC.

The act directed the DIDC to provide for the orderly phase-out of maximum interest rates that may be paid on time and savings deposits as rapidly as economic conditions warranted A primary consideration in determining when conditions warranted raising of elimm inating these ceilings was the effect of such changes on the safety and soundness of depository institutions. The act gave the DIDC broad discretion in choosing a method for phasing out the ceiling rates. One limitation was that the DIDC could not raise interest rate ceilings on all deposit categories above market interest rates before March 1986.

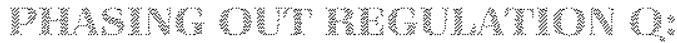

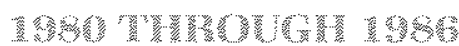

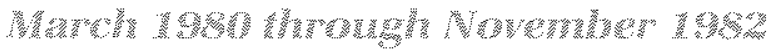

Some of the early actions of the DIDC were explicitly dictated by Congress. These were the establishment of nationwide NOW accounts, available in January 1981, and All Savers Certificates, avalable in October 1981." Of the early changes made at the discretion of the DIDC, the most significant involved raising of eliminating ceiling rates on categories of deposit liabilities with rather long maturities For instance, the DIDC's first action was to increase by 50 basis points the floating cetling rates on time deposits with maturities of at least 30 months, effective in June 1980. Actions effective in August 1981, December 1981 and May 1982 involved raising or eliminating ceiling rates on small time deposit accounts with initial maturities of 18 months or longer

In contrast, there were relatively minor changes in the ceiling rates on short-term deposits. The ony changes in the ceiling rates on MMCs, for instance, were the minof adjustments in June 1980 and November 1981 (table 1). The new categories of short-term

All Savers Certificates were a new category of deposits available at commercial banks and thrifts with a floating ceiling rate equal to 70 percent of the yield on one-year Treasury bills. Interest on these one-year certificates was exempt from federal income tax, up to $\$ 1,000$ of interest per taxpayer.

20 The DIDC took other types of actions that are not listed in table 1. Those other actions include restricting gifts by depository instifutions to depositors and adjusting the penalties for early withdrawal of deposits. deposits authorized in May and September of 1982 had relatively high minimum denominations.

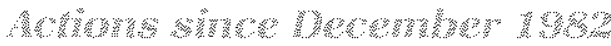

Depository institutions complaned to Congress that the DIDC was not moving last enough to allow them to meet the competition from money market mutual funds (MMMFs). The categoties of short-term time deposits on which depository institutions could pay rates close to market interest rates had minimum denominations that were substantialy higher than the minimum investments required by MMMFs. Investments in MMMFs continued growing much faster than smat time and savings deposits after the passage of the MCA in March 1980, a pattem that continued until late 1982 (chant 4 ).

The Gam-St Germain Act of 1982 directed the DIDC to create a category of deposits with tems that would be "directly equivalent to and competitive with money market mutual funds." 23 The DIDC responded by authorizing money market deposit accounts (MMDAs), available as of December 14,1982 , and Super NOW accounts, available as of January 5,1983 . The DIDC also specified a timetable for eliminating the remain ing ceiling rates, as indicated in table 1 . MMDAs and Super NOW accounts were subject to minimum balance requirements until January 1, 1986. The only remaining restriction on the interest rates paid on deposits is the prohibition of interest payments on demand deposits, which was not altered by the MCA.

\section{W

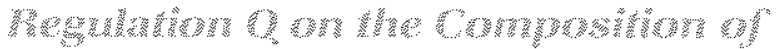

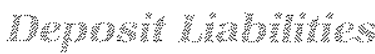

Depositors responded to the steps taken in phasing out Regulation $Q$ by shifting their funds to accounts on which they could receive higher returns. This is illustrated by the decline over time in the ratio of savings to small time deposits at all depository institutions, since the ceiling rates on small time deposits were raised and eliminated, while the ceilings on savings deposits changed little. In the three years prot to the introduction of MMCs, 1975-77, savings deposits were about 115 percent of small time deposits. That ratio has declined steadily since then, until, in 1985, savings deposits were only about 33 percent of small time deposits.

Other checkable deposits the interest-bearing

${ }^{2}$ Garcia (1983). 
checkable deposits that institutions may offer to individuals and nonprofit institutions / began growing rapidly after all depository institutions were permitted to offer these accounts in January 1981 (table 2). The interest rate ceilings on other checkable deposits have been the same for commercial banks, savings and loan associations, and mutual savings banks since 1981. Commercial banks accounted for over 81 percent of other checkable deposits in 1981, but their share has declined by about 10 percentage points since then.

Commercial banks have increased their share of small time deposits since 1980 (table 3 ). The rising share of small time deposits at commercial banks reflects the effect of several DIOC actions that removed the advantages that the ceiling rates had given to thrift institutions in competing for small time deposits. For instance, thrifts lost their rate advantage on MMCs on June 5, 1980. Several other DIDC actions put thrifts and commercial banks on an equal footing in competing for various categories of small time deposits.

The ceiling rate on savings deposits was 25 basis points higher at thrift institutions than at commercial banks throughout the period covered in table 3 unfil January 1,1984 , when the ceiling at commercial banks was increased by 25 basis points. Despite the rate disadvantage, the share of savings deposits at commercial banks rose slightly in 1979 and 1980. The relatively large drop in the share of savings deposits at commercial banks after 1982 appears to be related to the success of commercial banks in attracting MMDAs. Since MMDAs were authorized in December 1982 , the share at commercial banks has been around 60 percent of higher. Some of the funds that went into MMDAs at commercial banks came out of their own savings deposit liabilities.

Column 4 of table 3 nets out the trends in the first three columns. The share of small time and savings deposits plus MMDAs at commercial banks has risen steadily since 1979 , the year before the DIDC began removing the rate ceiling advantages of thrift institutions. Half of these deposits were at commercial banks in 1985, up from about 40 percent in 1979.

Thrift institutions accounted for about 8 percent of the time deposits in denominations of $\$ 100,000$ or more in 1978. As their share of deposits in the smallerdenomination categories declined, thrifts turned to the markef for large-denomination deposits to replace the small accounts they lost to commercial banks. By 1985, thrifts accounted for 36.5 percent of the largedenomination deposits.

Changes in the share of total time and savings de-

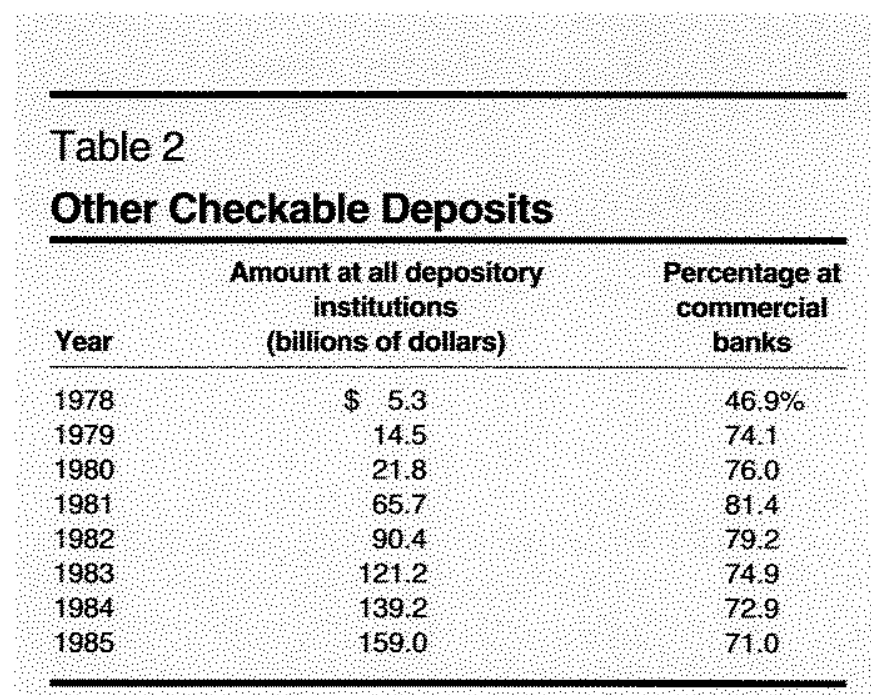

posits at commercial banks have been smaller than the changes in the specific categories. The share of total time and savings deposits at commercial banks rose about 4 percentage points from 1978 through 1982 and has been approximately unchanged since then. Since 1982, the funds that thrifts have raised by increasing their large-denomination deposits have been sufficient to offset their declining share of smalldenomination deposits. The reasons for these changes are explained in the appendix.

\section{ONGurans}

The policy of setting interest rate ceilings on deposits did not achieve its intended objectives. The original objectives in the $1930 \mathrm{~s}$, when celing rates were first imposed on commercial banks, were to induce relatively small barks to reduce their balances due from other banks and to increase the profits of the banking system by limiting the interest expense of banks. Relatively small banks instead increased the share of their assets held at other banks during the 1930s. During the first 30 years under Regulation $Q$. ceiling rates on time and savings deposits were sufficiently high to put no effective constraint on the interest rates paid by most commercial banks. The ceiling rates, however, may have constrained the growth of the most aggressive banks.

Regulation Q policy adopted in 1966 failed to achieve its objectives of constraining increases in interest rates and promoting a stable supply of mortgage credit. As a side effect, the policy adopted in 1966 also altered the allocation of wealth in the economy, causing those with relatively small savings to forego bil 
Table 3

Time and Savings Deposits at Commercial Banks As a Percentage of Deposits at All Depository Institutions

\begin{tabular}{llllllll}
\hline \\
\hline
\end{tabular}

lions of dollars in interest income they might otherwise have earned.

Congress acted in 1980 to establish a process for phasing out Regulation $Q$ because it observed that the regulation was not producing the intended effects. Congress concluded that interest rate ceilings created problems for depository institutions, discriminated aganst small saver's, and did not increase the supply of residential mortgage credit. The committee established by Congress accelerated the process of phasing out Regulation $\mathrm{Q}$ in 1982 after Congress directed it to authorize deposit accounts that were "directly equivalent to and competitive with money market mutual funds."

The steps taken to phase out Regulation $\mathrm{Q}$ have altered the distribution of deposits between commercial banks and thrift institutions, Before 1980, ceiling interest ates were higher at thrift institutions on deposits in denominations less than $\$ 100,000$. Thrifts lost this interest rate advantage as the ceiling rates were lifted. The share of small time and savings deposits at commercial banks rose from about 40 per. cent in 1979 to over 50 percent in 1985 , as commercial banks were allowed to compete with thrift institutions for these deposits on equal terms. Thrift institutions have responded by increasing their share of largedenomination time deposits. The distribution of totat time and savings deposits between commercial banks and thrift institutions has been essentially unchanged since 1982 .

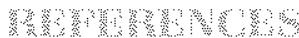

Arcelus, Francisco, and Allan $\mathrm{H}$, Metzer. "The Markets for Housing and Housing Services," Joumal of Money, Credit and Banking (February 1973), pp. 78-99.

Benston, George J. "Interest Payments on Demand Deposits and Bank Investment Behavior," Joumal of Polfical Economy (October 1964), pp. 431-49.

Berkman, Neil G. "Mortgage Finance and the Housing Cycle," Now England Economic Review (September/October 1979), pp. 54-76.

Clements, Mary Ann. "Deposit interest Rate Regulation and Competition for Personal Funds," this Review (November 1966), pp. $17-20$.

Clotfelter, Charles, and Charles Lieberman. "On the Distributional Impact of Federal Interesi Rate Restrictions," Joumal of Finance (March 1978), pp. 199-213.

Cox, Albert H., Jr. Regulation of Interest Rates on Bank Deposits, Michigan Business Studies, Vol. XVII, No. 4 (Bureau of Business Research, University of Michigan, 1966).

Depository Institutions Deregulation and Monetary Control Act of 1980. S. Rept. No. 96-640, 96 Cong. 2 Sess. (GPO, 1980).

De Rosa, Paul. "Mortgage Rationing and Residential Investment: Some Results from a Brainard-Tobin Model," Joumal of Money, Credit and Banking (February 1978), pp. 75 87.

Garcia, Gillian, et.al. "The Garn-St Germain Depository Institutions Act of 1982," Federal Reserve Bank of Chicago Economic Perspectives (March/April 1983).

Gilbert, R. Alton, and Jean M. Lovati. "Disintermediation: An Old Disorder with a New Remedy," this Review (January 1979), pp. $10-15$.

Haywood, Charles F., and Charles M. Linke. The Regulation of Deposit interest Rates (Association of Reserve City Bankers, 1968).

House Committee on Banking and Currency. Hearings on H.R. 14026, 80 Cong. 2 Sess. (GPO, 1966).

Temporary Interest Rate Controls, Report No. 1777, 89 Cong. 2 Sess. (GPO, 1966). 
Jaffee, Dwight $M$, and Kenneth T. Rosen. "Morigage Credit Availability and Residential Construction," Brookings Papers on Economic Activity (2:1979), pp. 333-76.

Kane, Edward J. "Short-Changing the Small Saver: Federal Government Discrimination against Small Savers during the Vietnam War," Journal of Money, Credit and Banking (November 1970), pp. $513-22$.

"Consequences of Contemporary Ceilings on Mortgage and Deposit Interest Rates for Households in Different Economic Circuntistances," in George M. von Furstenberg, ed., The Govemment and Capital Formation (Ballinger Publishing Company, 1980), pp. $401-41$.

Kilcollin, Thomas Eric, and Gerald A. Hanweck. "Regulation $Q$ and Commercial Bank Profitability," Research Papers in Banking and Financial Economics (Board of Governors of the Federal Reserve System, 1981)

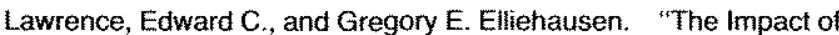
Federal interest Rate Regulations on the Small Saver: Further Evidence," Joumal of Finance (June 1981), pp. 677-84.

Linke, Charles M. "The Evolution of interest Rate Regulation on Commercial Bank Deposits in the United States, "Notional Banking Review (June 1966), pp. 449-70.

Martin, Preston. "A Case for Regulation $Q$," Joumal of the Federal Home Loan Bank Board (October 1970), pp. 1-6.

McKelvey, Edward F. "Interest Rate Ceilings and Disintermedia" tion:" Staff Economic Studies 99 (Board of Governors of the Federal Reserve System, 1978)

Metzer, Allan H. "Credit Avallability and Economic Decisions: Some Evidence from the Mortgage and Housing Markets, "Joumal of Finance (June 1974), pp. 763-78.
Moggan, Bruce W. "Ceitings on Deposit Interest Rates, the Saving Public and Housing Finance," Equity for the Small Saver, Hearings on S. Con. Res. 5 before the Subcommittee on Financial Institufions, Senate Committee on Banking, Housing and Urban Affairs, 96 Cong. 1 Sess. (GPO, 1979), p. 175

Peterson, Wiliam M. "The Effects of Interest Rate Ceilings on the Number of Banking Offices in the United States," Research Paper No. 8103 (Federal Reserve Bank of New York, 1981).

Pyle, David H. "The Losses on Savings Deposits from Interest Rate Regulation," Bell Joumal of Economics and Management Science (Autumn 1974), pp. 614-22.

"Interest Rate Celings and Net Worth Losses by Savers," in Kenneth E. Boulding and Thomas Frederick Wilson, eds., Redistribution through the Financial System (Praeger Publishers, 1978)

Ruebing, Charlote $E$. "The Administration of Regulation $Q$," this Review (February 1970), pp. 30-31.

Senate Committee on Banking and Currency. Hearings on S.3687, S.3627 and S.3529, 89 Cong. 2 Sess. (GPO, 1966).

Speliman, Lewis J. "Deposit Ceilings and the Efficiency of Financial Intermediation," Joumal of Finance (March 1980), pp. 129-36.

Startz, Richard. "Competition and Interest Rate Ceilings in Commercial Banking," Quarterly Joumal of Economics (May 1983), pp. $255-65$.

Taggart, Robert A., Jr. "Effects of Deposit Rate Celings: the Evidence from Massachusetts Savings Banks," Journal of Money, Credit and Banking (May 1978), pp. 139-57.

White, Lawrence J. "Price Regulation and Quality Rivalry in a Profitmaximizing Model: The Case of Bank Branching." Joumal of Money, Credit and Banking (February 1976), pp. 97 106.

\section{APPENDIX \\ The Effect of Phasing Out Regulation $Q$ on the Distribution of Deposits between Banks and Thrifts}

This appendix presents an analysis of the supply and demand for deposits to illustrate the influence of Regulation Q's phase-out on the distribution of deposits between commercial banks and thrifts. It analyzes the reasons for the rise in the share of smalldenomination accounts at banks and the reasons why the phase-out of the ceiling rates had such limited effects on the distribution of total deposits between banks and thrifts.

The major difference between figure 3 , used for the analysis in this appendix, and figure 2 is the influence of large-denomination deposits on the supply curves for deposits. At least some categories of deposits in denominations of $\$ 100,000$ or more have been exempt from Regulation $Q$ ceiling rates since June 1970; all deposits in denominations of $\$ 100,000$ or more have been exempt since May 1973. To investors, large-denomination deposits are alternatives to commercial paper, Treasury securities, and other money market instruments. Banks and thrifts are assumed to be price takers in the market for large-denomination deposits. The interest rate they must pay to attract these deposits is independent of the quantity they demand, and banks and thrifts must pay the market rate to attract any large-denomination deposits.

Until the steps taken to phase out Regulation $\mathrm{Q}$ (table 1), deposits in denominations of less than $\$ 100,000$ were subject to ceiling rates. The supply curves of deposits at banks and thrifts are designed to reflect the differences in ceiling rates based on denominations of deposits. As in figure 2 , the supply of small-denomination deposits at thrifts depends on the interest rates that banks pay on them, while the supply curve for banks depends on the rate paid by thrifts.

Banks and thrifts are assumed to be competitive. If 
Figure 3

Effects of the Phase-Out of Regulation 0 on the Deposits of Commercial Banks and Thrifts
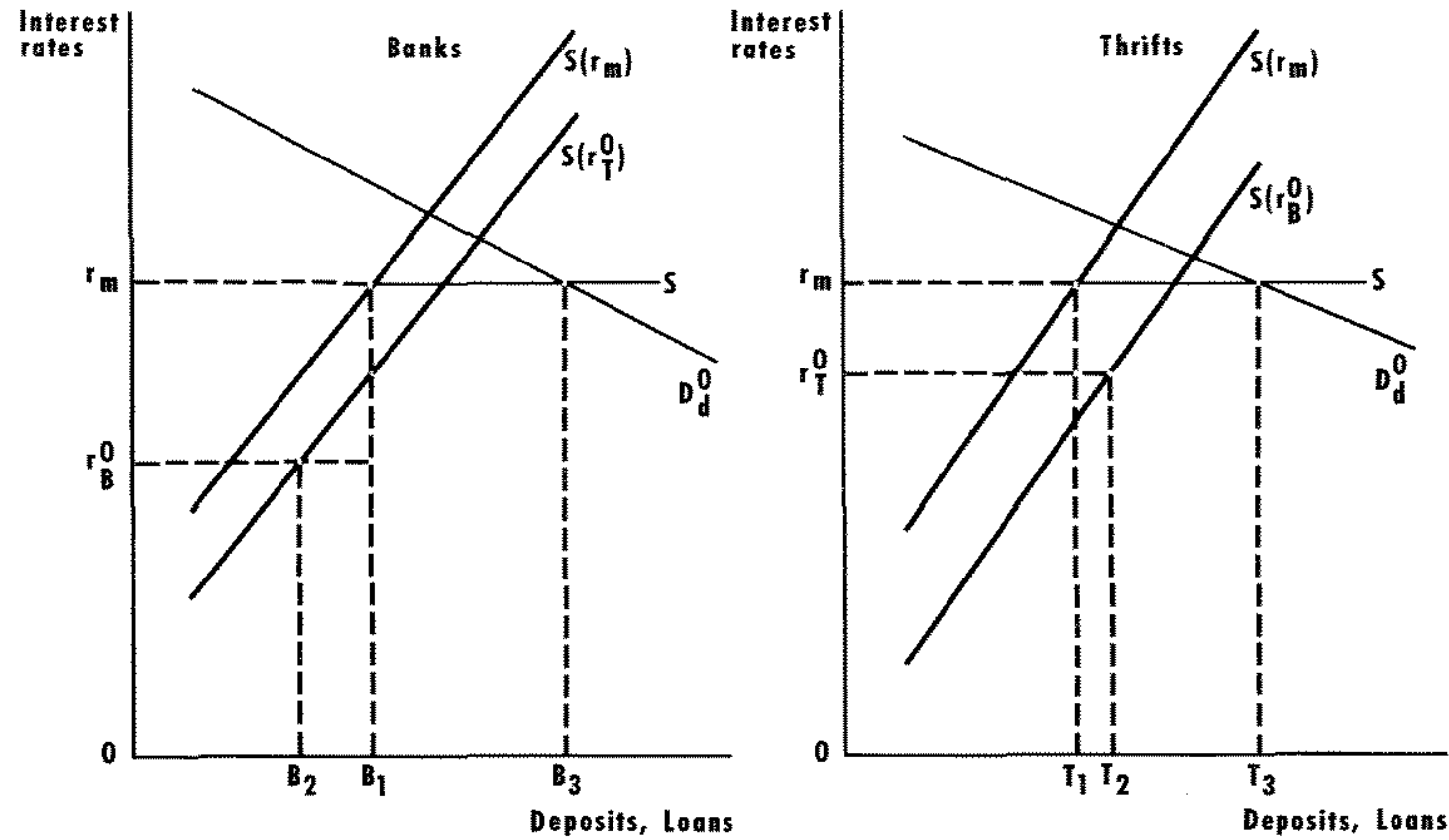

the celing rates on small-denomination deposits are above the market interest rate on large-denomination deposils, banks and thrifts are assumed to pay small depositors the market interest rate on large-denomination deposits $\left(r_{n}\right)$. If the levels of deposits they demand, given the market interest fate on large-denomination deposits, exceeds the levels of small-denomination deposits supplied at that market interest rate, banks and thrifts obtain the additional deposits in the market for large-denomination deposits. In terms of the symbols in figure 3 , the total quantity of deposits demanded by banks is $B_{i}$ they obtain $B_{1}$ as small-denomination doposits and the rest from the markef for large-denomination deposits. The smalldenomination deposits of thrifts are $T$, and their largedenomination deposits are $\mathrm{T}_{3}$ minus $\mathrm{T}_{\mathrm{E}}$

Suppose in contrast, that the ceiling rates on smalldenomination deposits are $r_{*}^{0}$ at thrifts and $r_{a}^{a j}$ at banks. Imposing the ceiling rates causes the supply curves of small-denomination deposits to shift to the right. Banks can attract a given level of small-denomination deposts at a lower interest wate with these ceiling mates in effect, since the celing ates limit the interest rate on the closest substifutes for deposit accounts at banks, which are deposit accounts at turits. These shitts in the supply curves to the right of $S\left(r_{\mathrm{ra}}\right.$ ) for banks and thrits are assumed to be propotional to the decline in the rates paid by the competing institutions when the ceiling rates are imposed. Imposing the ceiling rates is assumed to shift the supply curve further to the right at thrifts, since banks are subject to the lower ceiling rates.

Given the nature of the supply curves in figure 3 , imposing the ceiling rates $r_{\mathrm{F}}^{*}$ and $r_{3}^{*}$ causes the smalldenomination deposits of thrifs to rise from $T_{r} 10 T_{2}$ and small-denomination deposits of banks to fall from $B_{1}$ to $B_{3}$. The outcomes could be different, of course, if the supply curves had different slopes than those used in figure 3 . These ceiling rates do not affect the total quantity of deposits demanded by banks and Infifts, since $\mathrm{B}_{3}$ and $\mathrm{T}_{3}$ are detemined by the demand curves for total deposits and the market interest rate on largedenomination deposits.

Given the assumptions underlying figure 3 , the elimination of ceiling rates on small-denomination deposits would cause the share of small-denomination deposits at commercial banks to rise from $B$, divided by $B_{3}$ plus $T_{2}$ to $B_{2}$ divided by $B_{2}$ plus $T$ ). This change would not afed the distribution of total deposits between banks and thrits, but would cause the proportion of large-cenomination deposits at thifts to rise. Thus, the nature of the results derved from figure 3 are consistent with the actual outcomes gem corded in table 3 . 